MedieKultur | Journal of media and communication research | ISSN 1901-9726

\title{
Political communication research: New media, new challenges, and new opportunities
}

\section{Rasmus Kleis Nielsen}

MedieKultur 2014, 56, 5-22

Published by SMID | Society of Media researchers In Denmark | www.smid.dk The online version of this text can be found open access at www.mediekultur.dk

The rise of new media and the broader set of social changes they are part of present political communication research with new challenges and new opportunities at a time when many think the field is at an intellectual impasse (e.g., Bennett \& lyengar, 2008). In this article, I argue that parts of the field's problems are rooted in the way in which political communication research has developed since the 1960s. In this period, the field has moved from being interdisciplinary and mixed-methods to being more homogenous and narrowly focused, based primarily on ideas developed in social psychology, certain strands of political science, and the effects-tradition of mass communication research. This dominant paradigm has contributed much to our understanding of some aspects of political communication. But it is struggling to make sense of many others, including questions concerning people's experience of political communication processes and questions concerning the symbolic, institutional, and technological nature of these processes-especially during a time of often rapid change. To overcome this problem, I argue that the field of political communication research should re-engage with the rest of media and communication studies and embrace a broader and more diverse agenda. I discuss audience research and journalism studies as examples of adjacent fields that use a more diverse range of theoretical and methodological tools that might help political communication research engage with new media and the new challenges and new opportunities for research that they represent. 


\section{Introduction}

The rise of digital and networked information and communication technologies ("new media") and the broader set of social changes they are part of present political communication research with new challenges and new opportunities at a time when many think the field is at an intellectual impasse. Recently, two leading scholars have expressed concern that there is a "growing disjuncture between the prevailing research strategies and the sociotechnological context of political communication" (Bennett \& lyengar, 2008, p. 707). In their essay, W. Lance Bennett and Shanto lyengar suggest that the field has failed to develop theoretical and methodological tools to deal with new realities including audience fragmentation, information overload, and the spread of new technologies, including specialized databases and other tools used at the back-end of media organizations and by political organizations, as well as the more personal, portable, and interactive digital media used by ordinary citizens. Kevin Barnhurst (2011), another prominent critic, has argued that key terms like agenda-setting, framing, and public opinion, which have structured political communication research in the field since the 1960s, are in danger of turning into "zombie concepts" no longer in tune with how political communication processes actually work. Prominent journals have published special issues about political communication research facing a possible "crisis" (Sampedro, 2011) or at least a "critical moment" in terms of its development (Moy et al., 2012). The critics contend that the mainstream of political communication scholarship has developed ever more sophisticated tools for assessing shortterm individual behavioral and attitudinal effects of particular forms of media content and media exposure, but offers less in terms of understanding people's experiences of political communication processes or indeed the (changing) symbolic, institutional, and technological nature of these processes.

The concern is not a new one either; in one of his last essays (finished after his death by his colleague Miriam Metzger), the pioneering mass communication scholar Steven Chaffee argued that the rise of new media - at that time in particular the Internet in its "web 1.0" incarnation dominated by email, portals, and websites-seriously challenged several of the core assumptions of traditional political communication research (Chaffee \& Metzger, 2001). Returning to a distinction first made by Elihu Katz, Chaffee argued that established theories and methods were well-suited to understand "what media do to people", but had a harder time helping us understand "what people do with media" (Chaffee \& Metzger, 2001, p. 370). Some researchers argue that these changes should not make one jump to the conclusion that the dominant paradigm in political communication research has run out of steam, noting recent theoretical and methodological advances in our understanding of media effects (Holbert et al., 2010). But it is clear that there is growing concern that the field needs to change to continue to capture its object of analysis, during a time in which audiences are fragmenting (Neuman, 1992; Prior, 2007; Webster \& Ksiazek, 2012), media organizations are changing (Boczkowski, 2004; Ryfe, 2011; Anderson, 
2013), and political organizations are changing (Howard, 2006; Karpf, 2012; Kreiss, 2012; Nielsen, 2012a). As many societies seem to be undergoing more fundamental social transformations, described by some as a process of "detraditionalization" and individualization, as people seem less bound by traditional mores (Giddens, 2001; Beck \& Beck-Gernsheim, 2002), as the rise of a "network society" exceeds the nation-states that played such a large role in $19^{\text {th }}$ and $20^{\text {th }}$ century Western history (Castells, 1996; Sassen, 2006), and as a move away from the inherited social and political cleavages that defined much of the post-war period towards a situation in which new political issues concerning, for example, identity, rights, trust, and the environment, play a larger role (Ingelhart, 1997; Dalton, 2004), political communication too may need to change.

In this article, I will argue that part of the problem faced by political communication research, in terms of coming to terms with how political communication processes actually work under these changing sociotechnological circumstances, what they mean, and what their broader consequence are, arises from the way the field, especially as it is institutionalized and practiced in the United States-with ramifications for research across the world-has developed since the 1960s. Over the last decades, political communication research, as practiced in the most important journals and scholarly associations, has moved from being an interdisciplinary, mixed-methods, loosely structured field of inquiry to a more theoretically and methodologically homogenous academic field institutionally rooted in specific parts of political science and communication studies and intellectually primarily rooted in social psychology, certain strands of political science, and the effects tradition of mass communication research (Ryfe, 2001; Karpf et al., 2014; see also some of the interviews collected by Meyen, 2012).

This institutional and intellectual nexus has facilitated major advances in our understanding of particular questions concerning political communication, most notably in terms of media effects narrowly. But it has also distanced political communication research from the rest of media and communication studies and made it less likely that other questions are addressed-including broader media effects questions like those that Paul F. Lazarsfeld (1948) in his work on method categorized as concerned with longer-term organizational and institutional changes. Some of the questions that the dominant paradigm in political communication research tends to overlook-questions that concern media effects that go beyond short-term changes in individuals' attitudes and behaviors and include changes in organizational practices, institutional logics, and the structures and infrastructures of political communication, as well as the ways in which political actors and ordinary citizens make meaning of the political communication processes they participate in-are becoming more important today. This is in part because of the kind of sociotechnological changes that W. Lance Bennett, Shanto lyengar, Kevin Banhurst, and others have argued challenge the current theoretical and methodological foundations of political communication research. So far, these questions have rarely been pursued by mainstream political communication researchers, leaving us with a very partial understanding of how political 
communication processes function today. We know a lot about a little, and little about a lot more.

To overcome this problem, I will argue that political communication research, without severing its fruitful institutional and intellectual ties with social psychology and in particular political science, should re-engage with the rest of media and communication studies and especially with some of the theoretical and methodological currents that have been embraced by adjacent and even overlapping fields. I will offer audience research and journalism studies as examples of how related fields have engaged with many of the same sociotechnological changes that political communication research faces. Both of these fields provide examples of how a more diverse range of theoretical and methodological tools might help political communication research engage with the new challenges and new opportunities for research that "new media" and other contemporary sociotechnological changes represent.

In the first part of the article, I outline what I see as the main contours of the dominant paradigm of political communication research as it is currently institutionalized and practiced, especially in the United States, but also through the International Communication Association, and explain why this configuration is of wider relevance (even though I recognize my focus on North America and Western Europe is parochial). In the second part of the article, I highlight key elements of recent developments in other areas of communication studies - like audience research and journalism studies-that I argue political communication research could benefit from engaging with. In the final part, I discuss how political communication research could benefit from a broader and more diverse approach to its object of analysis without surrendering the advances made possible by the currently dominant paradigm.

\section{The state of political communication research during a period of sociotechnological change}

Political communication research, as we know it today in forums such as the International Communication Association, originated institutionally and intellectually in the United States in the 1960s and 1970s.

Institutionally, the field is built across communication studies and political science, recognized as a distinct subfield within each, and gathered around a single, shared journal, Political Communication, which is ranked in both disciplines and is, interestingly, published jointly by the political communication section of the International Communication Association (ICA) and the political communication section of the American Political Science Association (APSA). While some of the most influential works in political communication research have appeared in more general international communication studies journals, like the Journal of Communication, stronger links exist with U.S.-based political science journals, like the American Journal of Political Science, the American Political Science Review, 
and Public Opinion Quarterly. Judging from conference participation, preferred publication venues, and citation patterns, disciplines like sociology and most of the humanities (including rhetoric), fields that have historically played a key role in the development of political communication research, are largely absent from the field today.

Intellectually, the field as represented by the ICA and APSA sections and their joint journal is shaped primarily by inspiration drawn from social psychology, behavioralist currents with political science, and mass communication research in the "media effects" tradition (Ryfe, 2001). From social psychology, political communication researchers have adopted a focus on the attitudes and opinions of individuals and an emphasis on experimental and survey methods. From political science, the field has inherited a focus on politics understood primarily as a question of elections and governmental processes, and from the behavioralist parts of that discipline, skepticism towards qualitative research and broader sociologically-inspired theories, as well as an orientation towards quantification. From the mass communication research tradition, associated with Wilbur Schramm and later people like his student Maxwell McCombs, comes notions like agenda-setting, framing, and gate-keeping as well as the language of "effects" and "influence" and a particular interest in those effects that take the form of short-term observable changes in individual's behavior and expressed attitudes. Within this dominant paradigm of political communication research, lively, fruitful, high-level debates have played out around key questions like the impact of campaign communications, the effects of how news coverage frames issues, and how people get informed about political processes.

Political communication research, of course, is not completely dominated by this institutional and intellectual combination. There are other institutional forums-the political communication sections of, for example, the International Association of Media and Communication Research (IAMCR) and the European Association of Communication Research and Education (ECREA) draw overlapping, but not identical crowds, and a largely separate scholarly community seems to be growing around political marketing and political public relations. The International Journal of Press/Politics provides an alternative and well-respected forum for more comparative research on political communication, as do more general communication studies journals like the European Journal of Communication. There is also intellectual variation, with political communication researchers in parts of the Anglophone academic world-in the United Kingdom, for example-maintaining much closer ties with scholars working in fields like popular communication than has been the case in the United States, and with political communication research in continental Europe historically engaging far more directly with different strands of social theory including critical theory (in particular in Germany and the Nordic Countries) and semiology (in particular in France) (see Neveu, 1998; Czerwik, 2013). Even in the United States, individual political communication researchers, such as, to name a few, Gladys Engels Lang and Kurt Lang, Murray Edelman, and Susan Herbst, have done influential and widely-cited work that draws from very different theoretical and methodological perspectives, just as qualitative 
political sociologists, like Nina Eliasoph, William Gamson, and Katrine Cramer Walsh, as well as journalism studies scholars, like Daniel C. Hallin, Michael Schudson, and Timothy Cook, with their more historical and sociological approaches, are widely respected by political communication researchers.

But, despite these variations, the communication studies/political science combination, the ICA and APSA sections, and their journal Political Communication represent the core of political communication research today, if we see political communication research as a scientific field as such fields are understood by contemporary sociology of knowledge (defined intellectually by relatively shared, relatively standardized, dominant practices of knowledge production and institutionally by the key journals, conferences, and forms of training where they are maintained and reproduced (Swidler \& Arditi, 1994)). Adopting this perspective, one should not try to understand political communication research through the lens of individual biographies or the history of individual ideas, but by examining the field's main publication venues, most important professional associations, and the theories, methods, and substantial concerns that dominate work published and presented in these forums and represent the bulk of graduate training in many political communication programs. Much research is done that can be considered-and sometimes considers itself-as dealing with issues that are "political" and involve "communication", and could thus in a wider sense be seen as "political communication research" (everyone from Judith Butler to Henry Jenkins to Manuel Castells and many others). But the point of the sociology of science-perspective adopted here is that if such scholarly work is not explicitly integrated into and recognized by those working within the institutional structures that define and demarcate political communication research, then, whatever its qualities, it is not part of the field. Political communication research in this sense is practically, not theoretically or conceptually, defined. The field is understood in terms of what most of the people who explicitly identify themselves as political communication researchers-and are generally recognized as such by others who also do so-do. Seen in this way, the field is both methodologically and theoretically relatively homogenous. As shown elsewhere (Karpf et al., 2014), of the 188 articles published in the journal Political Communication over the ten years from 2003 to 2013, only 20 percent included some sort of qualitative methodological element (archival research, fieldwork, focus groups, interviews). The rest were quantitative, based on surveys, quantitative content analysis, or experiments. Seventy-six percent of the articles were built around theoretical notions like agenda setting, framing, and priming, whereas only 24 percent drew at least in part on theories like deliberative democracy, new institutionalism, uses and gratifications, or other approaches that-while widespread in communications studies - are not integrated parts of the dominant paradigm in political communication research. The notion of "mediatization" for example-increasingly popular in some other parts of media and communication studies-appears in the abstract and keywords of only one article throughout these ten years. Just nine articles mention the word. Even though one early articulation of the concept appeared in Political Communication almost fifteen 
years ago (Mazzoleni \& Schulz, 1999), it has yet to be embraced by the mainstream of political communication research.

The main purpose of political communication research in the tradition discussed here has been to understand the influence of messages coming from political actors and media organizations and mediated via mass media like television or printed newspapers on the political attitudes and behavior of lay individuals. The theoretical master terms are agenda setting, framing, and priming, coupled with notions like public opinion (understood as an aggregate of individual attitudes) and political behavior, as well as "media effects" (understood as immediate and often short-term effects on lay individuals' attitudes and behaviors). The most common methods have been surveys, quantitative content analysis, and increasingly experiments. After fifty years of research, the results have been rich. Our understanding of the electoral and potentially democratic implications of campaign communications and news coverage has grown, just as our knowledge of the scale, scope, and causal mechanisms behind media effects has become much more sophisticated and precise (e.g., Holbert et al., 2010). But the very same field that has produced these impressive results-institutionally and intellectually structured around the ICA and APSA sections and their joint journal-also seems, as many have argued (Chaffee \& Metzger, 2001; Bennett \& lyengar, 2008; Barnhurst, 2011; Karpf et al., 2014), increasingly unable to understand or even conceptualize a broader range of questions concerning political communication in the changing sociotechnological context of post-industrial affluent democracies. Especially questions concerning organizational and institutional changes in how messages are produced, mediated, and received, understood, and perhaps remixed by citizens fall largely outside the dominant paradigm. Can one understand ordinary people's own use of social networking sites for political purposes simply through the lens of attitudinal and behavioral effects? Can we understand what the emergence of digital intermediaries like dominant search engines means for political communication processes this way? The dominant paradigm provides us with powerful tools for addressing some aspects of these phenomena, but only some. To analyze other aspects, political communication research may draw inspiration from, for example, audience research (concerned with, amongst other things, reception, meaning-making, and sometimes the active use of media by individuals) and journalism studies (concerned with, amongst other things, how the development of new sociotechnological configurations are changing the production and dissemination of news).

\section{Audience research and journalism studies confront sociotechnological changes}

If, as a growing number of prominent critics argue, the dominant paradigm in political communication research, for all its qualities in terms of understanding what media do to people, has been less useful in understanding what people do with media (and indeed what organizations do with media and what media do to organizations) - an especially 
pressing problem in times of often rapid sociotechnological changes-how might the field overcome this possible intellectual impasse? In this section, I will offer some suggestions through a discussion of how two adjacent (even overlapping) fields within communications studies, namely audience research and journalism studies, have confronted many of the same sociotechnological changes that are challenging political communication research as we know it. For reasons of space, each section will necessarily have to be brief and selective. The purpose here is not to provide full overviews of each of these fields, but to use these two fields as projective devices to draw contrasts that help highlight a few aspects of what political communication research might learn from them. I will deal first with audience research, then with journalism studies.

Audience research is a central field of inquiry in media and communication studies and has been for a long time. In fact, the field is so integrated into the discipline that it is not a separate section in, for example, the ICA (though sections exist in both IAMCR and ECREA). Only in 2003 was Participations launched as a dedicated journal specifically for audience research. Audience research scholars therefore have had to make their work relevant for more diverse readerships in general communication studies journals like Communication Research, Media, Culture \& Society, etc., and thus also been exposed to editorial comments and peer review from a more diverse range of scholars. Like political communication research, audience research owes a great debt to the pioneering work of primarily quantitatively and behaviorally-oriented scholars like Paul F. Lazarsfeld and to the mass communication and media effects traditions (O'Neill, 2011). But the field has also maintained an ongoing engagement with qualitative empirical researchers drawing on cultural studies, sociology, and social theory more broadly - traditions more interested in meaningmaking practices than in effects on attitudes and behaviors narrowly speaking. In the 1980s and early to mid-1990s, major debates in audience research concerned the proper balance between quantitative and qualitative methods, as well as between different theoretical approaches to understanding how media content influenced recipients ("active audiences" versus various conceptions of centralized and unequal forms of cultural power) (e.g., Katz, 1980; Schrøder, 1987; Jensen \& Rosengren, 1990). By the mid-1990s, these disputes seem to have been replaced by a more peaceful coexistence as well as examples of fruitful collaborations (Livingstone, 1996).

From the late 1990s onwards, however, audience research-like political communication research-has increasingly confronted sociotechnological changes that seriously challenge many of the core assumptions common to both quantitative and qualitative researchers, shared by behavioralists and cultural studies scholars. The central concept of the "mass audience", for example, was challenged by accelerated audience fragmentation as first multi-channel television and later digital media took off (Katz, 1996). Questions regarding the social context of media use were complicated by the emergence of new, distributed, technologically mediated contexts like online-enabled communities of interest (Jenkins, 2006). The idea of a "television audience" or a "radio audience" increasingly was 
confronted with the intellectual challenges posed by phenomena such as technological convergence, multi-screen media use, and streaming and IP-television viewing via Internetenabled and increasingly mobile devices (e.g., Ling, 2008; Livingstone, 2009). Practices of "audiencing" are no longer easily confined to a few paradigmatic situations (newspaper in the morning at the breakfast table, television in the evening in the living room) but increasingly ubiquitous as media, and hence media use, are increasingly found everywhere (e.g., Silverstone, 2005). A field of research that had seen people primarily as (occasional) receivers of mediated content (even when seen as highly active interpreters of that content) had to contend with increasingly interactive forms of media use and the potential for widespread forms of participation not part of the late- $20^{\text {th }}$ century mass media environment (e.g., Napoli, 2010). Well-understood forms of audience engagement like reading, listening, and viewing are changing, and increasingly supplemented by new practices like searching, spreading, and participating (e.g., Nightingale, 2011).

In contrast to political communication research, where the basic conception of lay media users has remained largely unchanged, audience researchers began to retool theoretically at an early stage. Audiences are increasingly seen as cross-media rather than mediaspecific (Schrøder \& Kobbernagel, 2010), and the basic notion of ordinary people's relation to media has gone from a focus on reception to a focus on the broader concept of use, even as whether, when, and how people do actually participate or use interactive features are left as empirical rather than theoretical questions (Lievrouw \& Livingstone, 2006; Livingstone, 2013). Methodologically, audience research in the early 2000 s has remained robustly mixed-methods (after the sometimes contentious debates of the 1980s and 1990s), with quantitative and qualitative research not simply co-existing, but often being combined in larger research projects, such as the work of Nick Couldry, Sonia Livingstone, and Tim Markham (2010) on "mediated public connections", which employs a combination of survey research, repeat in-depth interviews, and personal diaries to examine the relation between media consumption and public engagement in the United Kingdom. ${ }^{2}$

Despite the progress made, audience research of course also faces many challenges. Old theoretical questions over agency versus power inequalities as well as methodological questions concerning the ability of quantitative research to capture the realities of social life and the generalizability of qualitative research remain relevant. New questions have arisen, such as those concerning the blurring of established genres like fact and fiction and the challenge to traditional public/private and individual/group distinctions represented by the rise of new social contexts for media use and reception in often ephemeral technologically-mediated social networks. Research is still heavily oriented towards the Western world and rarely comparative. The purpose here, as said, is not to provide a complete overview of where the field is, how it got there, and where it might be heading, but to highlight a few pertinent differences between audience research and political communication research. Audience research has confronted many of the same contextual sociotechnological changes that political communication research grapples with. But the field 
has dealt with them differently, through an ongoing engagement with cultural studies and social theory, a reconceptualization of core categories including audiencing and audiences, through active dialogue with other areas of media and communication studies, and on the basis of an enduring commitment to mixed methods studies focused not only on exposure and behavior, but also meaning and situated practices. Without surrendering the traditional question of "what media do to people" or their deep links to the media effects tradition, audience researchers are increasingly also addressing the question of "what people do with media" as a bewildering and growing array of media are increasingly integral to more and more aspects of life. That has not been the case to the same extent for political communication research, a field that could advance our understanding of contemporary political communication processes by paying more attention to the citizens' own experience of and (sometimes active) engagement with political communication.

Journalism studies, in contrast to audience research, has become very strongly institutionalized as a distinct field over the last decade. Historically more closely associated-at least in the Anglophone world and much of continental Europe-with professional schools offering vocational training, and with associations with an emphasis on education, like the Association for Education in Journalism and Mass Communication (AEJMC) in the United States, journalism studies is today increasingly integrated into the academic institutional structures of communication studies. The journalism studies section of ICA is one of the biggest and fastest-growing in the association, and a rising number of academic journals specialize in the area, including Journalism Studies, Journalism Practice, Digital Journalism, and Journalism: Theory, Practice, Critique. Like audience research, journalism studies for years has included strong strands of both quantitative and qualitatively-oriented research (e.g., Löffelholtz \& Weaver, 2008). At the quantitative end of the field, there is strong overlap with political communication research, as surveys and quantitative content analysis are some of the most widely used methods and key concepts include notions of agenda-setting and framing that are familiar to political communication scholars (there is also considerable overlap at the level of individual researchers here, especially in European countries where campaign advertising plays a smaller role in political communication and news media, relatively speaking, a bigger role). At the qualitative end of the field, scholars use in-depth interviews and ethnographic fieldwork to understand daily journalistic work practices as well as historical methods to track the development of the profession and the news media for which most journalists work.

As with political communication research and audience studies, sociotechnological changes have transformed journalism studies' object of analysis in recent years. Tabloidization, the rise of infotainment, and the increasing popularity of soft news and satirical current affairs programs have led journalism studies scholars to reconsider the question "what is news?" (Hermida et al., 2011; Williams \& Delli Carpini, 2011). New opportunities for self-publishing, first by personal websites, then via blogs, and now through social networking sites like Facebook and microblogging services like Twitter, the phenomenon of citizen 
journalism, and an increased use of user generated content (UCC) by legacy news media organizations have put the questions "what is journalism?" and "who is a journalist?" on the agenda (Deuze, 2005). The increasing importance of digital platforms has disrupted the business models of many legacy media (Nielsen, 2012b). At a more fundamental level, sociotechnological changes in how content is produced, disseminated, consumed-and sometimes remixed and shared-raises the question of what mix of continuity and change best captures what is happening to journalism and news (Tewksbury \& Rittenberg, 2012) and overlaps to a considerable degree with the concerns of some audience researchers (e.g., Bird, 2011).

This transitional moment in journalism has, amongst other things, generated a new wave of newsroom ethnographies in journalism studies, in the United States led by Pablo Boczkowski's study of how different newspapers in America engaged with early generations of digital media (Boczkowski, 2004), recently complemented by studies by David Ryfe (2011) and C. W. Anderson (2013) of small-town and metropolitan daily newspapers, as well as work by others on the broader and more heterogeneous networks of professional innovators, technologists, and policy reformers that form around journalism (Lewis, 2012; Lewis \& Usher, 2013; Ananny, 2013). All of these studies have combined a return to methodological tools that enabled seminal contributions to the field in the 1970s (e.g., Tuchman, 1978; Gans, 1979) and an active engagement with more recent theoretical developments in both sociology and in science and technology studies. This new wave of methodologically qualitatively-based and theoretically sociologically-inspired empirical research in journalism studies has thrived alongside advances in other parts of the field in terms of developing more clearly defined concepts and methods for consistent quantitative content analysis (e.g., Umbricht \& Esser, 2013) as well as more multi-country comparative studies of political information environments (e.g., Curran et al., 2009), journalistic role-conceptions (e.g., Hanitzsch et al., 2011), and mixed-methods comparative analyses of whole media systems (e.g., Hallin \& Mancini, 2004).

Journalism studies, like audience research, shows how methodological and theoretical diversity can not only co-exist, but in fact can help scholars engage with the new challenges and new opportunities accompanying sociotechnological change. Again, the purpose here has not been to provide a full overview of recent developments in the field-let alone the challenges it faces - but to suggest that though journalism studies is quite different from audience research in its institutional structure-strongly oriented towards its own established sections and journals-intellectually, it too provides an example of a field that has changed to confront the challenges that sociotechnological transformations represent. In journalism studies as in audience research and political communication research, scholars face many ongoing theoretical and methodological problems, both familiar ones inherited from previous generations as well as questions raised by current developments. But the field of journalism studies, to a greater extent than political communication research, has embraced qualitative methods and theoretical approaches originally developed in sociol- 
ogy and science and technology studies in its attempts to come to terms with contemporary sociotechnological changes. Especially in the new newsroom ethnographies and in studies of the various networks forming around journalism and newswork, journalism studies has moved beyond questions of "what do media do to people?" and "what do people do with media?" and engaged with what Paul F. Lazarsfeld, in his work on method, considered questions of the longer-term organizational and institutional effects of media (and changes in media technologies and systems). To follow up on the pioneering work of scholars like Timothy Cook (1998), on the news media as a "political institution", after more than a decade of often rapid change in both media and politics, political communication researchers could embrace a similar approach.

\section{Could more diverse political communication research overcome the field's impasse?}

As made clear from the outset, many leading political communication researchers have argued that the field of political communication research faces an intellectual impasse as it struggles to come to terms with how political communication processes function in a time of often rapid and profound sociotechnological change (e.g., Chaffee \& Metzger, 2011; Bennett \& lyengar, 2008; Barnhurst, 2011). In this paper, I have argued that one of the origins of this impasse is the development from the 1960s onwards, especially in the United Statesbut through associations like the ICA and journals like Political Communication with global implications - of a particular paradigm of political communication research constructed around elements appropriated from social psychology, behavioralist political science, and the media effects-tradition of mass communication research.

The "dominant paradigm" of media effects that Todd Gitlin (1978) identified in the late 1970 s no longer dominates media research as such. But many elements of it have remained central to the field of political communication research even as the rest of media and communication studies has become much more theoretically and methodologically diverse. At a time when especially the increased importance of new digital and networked information and communication technologies present the field of political communication research with new intellectual challenges, I have suggested that the ways in which adjacent scholarly fields like audience research and journalism studies have reacted to sociotechnological changes in their (overlapping) objects of analysis may provide a model for how political communication research can make progress. Both of these fields have seen real innovation driven by intellectual diversity. Political communication research in principle is committed to the same kind of theoretical and methodological diversity: Political Communication, in the words of the journal's aims and scope section, "welcomes all research methods and analytical viewpoints that advance understanding of the practices, processes, and policy implications of political communication in all its forms." ${ }^{3}$ But it has in practice, with some prominent exceptions, been dominated by mostly behavioralist and mostly quantitative 
research and has been oriented towards traditional aspects of the subject matter. Both audience research and journalism studies provide practical examples of how fields with very similar interests have successfully embraced a more diverse range of methods and engaged with a broader range of theories, including qualitative methods like focus groups, interviews, and ethnographic fieldwork, and a broader range of theories coming out of both sociology and science and technology studies. Both fields have used these intellectual tools to produce a wider range of empirical insights into how communication processes work, what they mean, and what their consequences are, at the individual, institutional, and infrastructural levels. Similar methods and theories might help political communication research overcome its current impasse, but of course their value can only be proven in practice through empirical work on political communication processes.

It is therefore worth highlighting a few recent cases that can illustrate their potential. An example of an innovative appropriation of methods and theories common to audience research, for the purposes of political communication research, is Stephen Coleman's How Voters Feel (2013), which analyzes people's own experiences and perceptions of political participation on the basis of in-depth interviews and theoretical concepts from cultural sociology, and moves far beyond what can be captured in standardized survey questions. The book points towards a wider range of questions concerning how lay people experience and perceive a wide range of forms of political communication, from news coverage to campaign advertising to interpersonal conversation. These are questions about which we political communication researchers know little compared to the detailed qualitative understanding audience research offers when it comes to people's engagement with various forms of popular culture and entertainment media (or indeed compared to political actors themselves, many of whom use, for example, focus group research). An example of an inventive use of methods and theories common to journalism studies, in a way that address questions at the core of political communication research, is Andrew Chadwick's work on the implications of interactions between "new" and "old" media for politics and power in contemporary Western democracies. In The Hybrid Media System (2013), Chadwick embraces classic qualitative methods and sociological theories associated with the 1970s field research-based studies of (political) news production pioneered in the United States. But he also puts the changing role of technology at the center of his analysis in a way that is closer to how contemporary science and technology studies have been adopted by some journalism studies scholars than it is to the resolutely socially-oriented fieldwork of, say, Herbert J. Gans. Again, Chadwick's work points towards a set of questions concerning the everyday (socio-technical) practice of political communication that political communication researchers know less about than journalism studies scholars know about the changing nature of journalistic work, news organizations, and the technologies integral to both.

But it is important to underline that-examples aside - the point of this article is not to present a full research agenda for political communication. That would be both presumptuous and inappropriate. As Lazarsfeld wrote in The Language of Social Research, the task 
of methodologists, theorists, and others reflecting on scientific practice is not to tell other people what they should do, but to tell others "what they have done, or might do" (Lazarsfeld \& Rosenberg, 1955, p. 4). The purpose here is simply to highlight that a particular kind of methodological and theoretical diversity (one that includes, in addition to quantitative methods and behavioralist theories, more qualitative research and theoretical inspiration from sociology and science and technology studies) has helped adjacent scholarly fields advance as they faced some of the same new challenges and new opportunities confronting political communication research. Interestingly, some of the same intellectual tools have also been brought to bear by political communication researchers working on various aspects related to "new media" (digital and networked information and communication technologies). This is an area of research that the dominant paradigm is only beginning to express interest in and where much pioneering work has therefore appeared in more theoretically and methodologically diverse general communication studies journals like Information, Communication \& Society, Journal of Computer-Mediated Communication, and New Media \& Society. (In these forums, reviewers will expect authors to be up-to-date with work in media and communication studies more generally, not just political communication research.) Political Communication, in contrast, has published just 18 articles from 2003 to 2013 focused on some form of digital media-less than 10 percent of the total during a period in which the number of Internet users globally has increased by nearly two billion.

What would increased methodological and theoretical diversity mean for the dominant paradigm in political communication research? The mainstream of political communication research, with its origins in social psychology, behavioralist political science, and the media effects tradition of mass communication research may be the closest thing political communication research has to a normal science paradigm in Kuhn's sense of a "disciplinary matrix" of shared methodological, theoretical, and even metaphysical commitments. But it is not universally agreed-upon as the only legitimate approach to the study of political communication, nor is it typically presented as such when confronted with alternatives or supplements. The study of political communication, in this respect, remains more like the rest of the social sciences and humanities, a field involving several different approaches, sometimes complementary, sometimes competing, sometimes even incommensurable. Precisely because the dominant paradigm is not a total paradigm and already co-exists with other ways of analyzing political communication, increased methodological and theoretical diversity need not involve a wholesale "scientific revolution" and rejection of the existing order. Political communication research can continue to benefit from its strong and productive intellectual and institutional links to social psychology and political science while also engaging more systematically with theoretical and methodological work in the rest of media and communication studies and beyond. Academic work is institutionally competitive at least as often as it is collaborative, as there are limits to the number of articles and books published, prizes awarded, and conference papers accepted. But academic work need not be a zero sum game, especially when dealing with different aspects of diverse and 
ever-changing objects of analysis. Increased engagement with more mixed and qualitative methods and with a wider range of theories, including more sociological ones, therefore need not come at the direct expense of the currently dominant paradigm. One can call for a new generation of theoretically interdisciplinary and methodologically diverse work, akin to the research that defined the field from the 1930s to the 1950s, without rejecting wholesale the theoretical and methodological tools, let alone the achievements, of the work done since the 1960s (e.g., Karpf et al., 2014). As the examples of audience research and journalism studies suggest, more diverse approaches can co-exist and complement each other even when they sometimes have robust disagreements of a substantial, methodological, and theoretical nature. They can even mutually enrich each other.

If we want to understand how political communication processes work, what they mean, and what their consequences are, especially in a time of sociotechnological change challenging many of our inherited assumptions, we need to move beyond the important but narrow question of what impact mediated messages have on individual's attitudes and political behavior and engage also with the broader questions of media effects that Paul F. Lazarsfeld (1948) saw as pertaining to the longer-term and often institutional effects of changes in the economic, political, social, and technological structure of media. To do so, we need more diverse theoretical and methodological tools and a broader research agenda. I have suggested that audience research and journalism studies specifically-and media and communication studies more generally - can provide us with some of them. Political communication research on new media and the new challenges that they come with has already provided some example of how these new opportunities may be seized, and points the way to a more diverse future for political communication research, past the field's current intellectual impasse.

\section{Acknowledgements}

This article has benefited immensely from ongoing conversations with David Karpf and Daniel Kreiss, as well as from comments from Kim Schrøder.

\section{References}

Ananny, M. (2013). Press-Public Collaboration as Infrastructure Tracing News Organizations and Programming Publics in Application Programming Interfaces. American Behavioral Scientist, 57(5), 623-642. doi:10.1177/0002764212469363

Anderson, C.W. (2013). Rebuilding the news. Philadelphia: Temple University Press.

Barnhurst, K.G. (2011). The New "Media Affect" and the Crisis of Representation for Political Communication. The International Journal of Press/Politics, 16(4), 573-593. doi:10.1177/1940161211415666

Beck, U., \& Beck-Gernsheim, E. (2002). Individualization. London ; Thousand Oaks, Calif: Sage. 
Bennett, W.L., \& Iyengar, S. (2008). A New Era of Minimal Effects? The Changing Foundations of Political Communication. Journal of Communication, 58(4), 707-731.

Bird, S.E. (2011). Seeking the Audience for News: Response, News Talk, and Everyday Practices. In V. Nightingale (Ed.), The Handbook of Media Audiences (pp. 489-508). Wiley-Blackwell. Retrieved from http://onlinelibrary.wiley.com/doi/10.1002/9781444340525.ch25/summary

Boczkowski, P.J. (2004). Digitizing the News. Cambridge, Mass: MIT Press.

Castells, M. (1996). The Rise of the Network Society. Oxford: Blackwell Publishers.

Chadwick, A. (2013). The hybrid media system. New York: Oxford University Press.

Chaffee, S.H., \& Metzger, M.J. (2001). The End of Mass Communication? Mass Communication and Society, 4(4), 365-379. doi:10.1207/S15327825MCS0404_3

Coleman, S. (2012). How voters feel. Cambridge: Cambridge University Press.

Cook, T.E. (1998). Governing with the News. Chicago: University of Chicago Press.

Couldry, N., Sonia M. Livingstone, \& Tim Markham. (2010). Media consumption and public engagement (Rev. and updated ed.). Basingstoke: Palgrave Macmillan.

Curran, J., lyengar, S., Brink Lund, A., \& Salovaara-Moring, I. (2009). Media System, Public Knowledge and Democracy. European Journal of Communication, 24(1), 5-26. doi:10.1177/0267323108098943

Czerwick, E. (2013). Ulrich Sarcinelli und die Anfänge der Politischen Kommunikationsforschung in Deutschland - Versuch einer Würdigung. In E. Czerwick (Ed.), Politische Kommunikation in der repräsentativen Demokratie der Bundesrepublik Deutschland (pp. 11-36). Springer Fachmedien Wiesbaden. Retrieved from http://link.springer.com/chapter/10.1007/978-3-658-01016-4_1

Dalton, R.J. (2004). Democratic challenges, democratic choices. Oxford: Oxford University Press.

Deacon, D., \& Keightley, E. (2011). Quantitative Audience Research: Embracing the Poor Relation. In V. Nightingale (Ed.), The Handbook of Media Audiences (pp. 302-319). Wiley-Blackwell. Retrieved from http:// onlinelibrary.wiley.com/doi/10.1002/9781444340525.ch15/summary

Deuze, M. (2005). What is journalism? Professional identity and ideology of journalists reconsidered. Journalism, 6(4), 442-464. doi:10.1177/1464884905056815

Gans, H.J. (1979). Deciding What's News. New York: Pantheon Books.

Giddens, A. (1991). Modernity and Self-Identity. Stanford, Calif: Stanford University Press.

Gitlin, T. (1978). Media Sociology: The Dominant Paradigm. Theory and Society, 6(2), 205-253.

Hallin, D.C., \& Mancini, P. (2004). Comparing Media Systems. Cambridge: Cambridge University Press.

Hanitzsch, T., Anikina, M., Berganza, R., Cangoz, I., Coman, M., Hamada, B., ... Yuen, K.W. (2010). Modeling Perceived Influences on Journalism. Journalism \& Mass Communication Quarterly, 87(1), 5-22. doi:10.1177/107769901008700101

Hermida, A., Fletcher, F., Korell, D., \& Logan, D. (2012). Share, Like, Recommend. Journalism Studies, 13(5-6), 815-824. doi:10.1080/1461670X.2012.664430

Holbert, R.L., Garrett, R.K., \& Gleason, L.S. (2010). A New Era of Minimal Effects? A Response to Bennett and lyengar. Journal of Communication, 60(1), 15-34. doi:10.1111/j.1460-2466.2009.01470.x

Howard, P.N. (2006). New Media Campaigns and the Managed Citizen. Cambridge: Cambridge University Press.

Inglehart, R. (1997). Modernization and postmodernization. Princeton, NJ; Chichester: Princeton University Press.

Jenkins, H. (2006). Convergence Culture. New York: New York University Press.

Jensen, K.B., \& Rosengren, K.E. (1990). Five Traditions in Search of the Audience. European Journal of Communication, 5(2), 207-238. doi:10.1177/0267323190005002005

Karpf, D. (2012). The MoveOn effect. New York: Oxford University Press. 
Karpf, D.A., Kreiss, D., \& Nielsen, R.K. (2014). A new era of fieldwork in political communication research? In

L. Lievrouw (Ed.), Challenging Communication Research (pp. 43-57). New York: Peter Lang.

Katz, E. (1980). On Conceptualizing Media Effects. Studies in Communication, 1, 119-141.

Katz, E. (1996). And Deliver Us from Segmentation. Annals of the American Academy of Political and Social Science, 546, 22-33. doi:10.2307/1048167

Kreiss, D. (2012). Taking our country back. New York: Oxford University Press.

Kuhn, T.S. (1996). The structure of scientific revolutions (3rd ed.). Chicago, IL: University of Chicago Press.

Lazarsfeld, P.F. (1948). Communication Research and the Social Psychologist. In W. Dennis (Ed.), Current Trends in Social Psychology. Pittsburgh, Pa: University of Pittsburgh Press.

Lazarsfeld, P.F., \& Rosenberg, M. (Eds.). (1955). The Language of social research. Glencoe, Ill: Free Press.

Lewis, S.C. (2012). The Tension Between Professional Control and Open Participation. Information, Communication \& Society, 15(6), 836-866. doi:10.1080/1369118X.2012.674150

Lewis, S.C., \& Usher, N. (2013). Open source and journalism. Media, Culture \& Society, 35(5), 602-619. doi:10.1177/0163443713485494

Lievrouw, L.A., \& Livingstone, S. M. (Eds.). (2006). Handbook of New Media (Updated edition). London: SAGE. Livingstone, S. (1996). On the continuing problems of media effects research. In J. Curran \& M. Gurevitch (Eds.), Mass media and society (pp. 305-324). London: Edward Arnold.

Livingstone, S. (2009). On the Mediation of Everything: ICA Presidential Address 2008. Journal of Communication, 59(1), 1-18. doi:10.1111/j.1460-2466.2008.01401.x

Livingstone, S. (2013). The Participation Paradigm in Audience Research. The Communication Review, 16(1-2), 21-30. doi:10.1080/10714421.2013.757174

Löffelholz, M., \& Weaver, D.H. (Eds.). (2008). Global Journalism Research. Malden, MA: Blackwell Pub.

Mazzoleni, G., \& Schulz, W. (1999). "Mediatization" of Politics: A Challenge for Democracy? Political Communication, 16(3), 247-261. doi:10.1080/105846099198613

Meyen, M. (2012). ICA Fellows: A Collective Biography. International Journal of Communication, 6. Retrieved from http://ijoc.org/index.php/ijoc/article/view/1513

Moy, P., Bimber, B., Rojecki, A., Xenos, M., \& lyengar, S. (2012). Transnational Connections: Shifting Contours in Political Communication Research. International Journal of Communication, 6, 247-254.

Napoli, P.M. (2010). Revisiting "mass communication" and the "work" of the audience in the new media environment. Media, Culture \& Society, 32(3), 505-516. doi:10.1177/0163443710361658

Neuman, W.R. (1991). The Future of the Mass Audience. Cambridge [England]: Cambridge University Press.

Neveu, E. (1998). Media and politics in French political science. European Journal of Political Research, 33(4), 439-458. doi:10.1111/1475-6765.00390

Nielsen, R.K. (2012a). Ground Wars: Personalized Communication in Political Campaigns. Princeton: Princeton University Press.

Nielsen, R.K. (2012b). Ten Years That Shook the Media World. Oxford: Reuters Institute for the Study of Journalism.

Nightingale, V. (2011). Introduction. In V. Nightingale (Ed.), The Handbook of Media Audiences (pp. 1-15). Wiley-Blackwell. Retrieved from http://onlinelibrary.wiley.com/doi/10.1002/9781444340525.ch/summary

Prior, M. (2007). Post-Broadcast Democracy. New York: Cambridge University Press.

Ryfe, D. (2012). Can journalism survive? Cambridge: Polity.

Ryfe, D.M. (2001). History and Political Communication. Political Communication, 18(4), 407-420. doi:10.1080/10584600152647119

Sampedro, V. (2011). New Trends and Challenges in Political Communication. The International Journal of Press/Politics, 16(4), 431-439. doi:10.1177/1940161211418291 
Sassen, S. (2006). Territory, Authority, Rights. Princeton, N.J: Princeton University Press.

Schrøder, K.C. (1987). Convergence of Antagonistic Traditions? The Case of Audience Research. European Journal of Communication, 2(1), 7-31. doi:10.1177/0267323187002001002

Schrøder, K.C., \& Kobbernagel, C. (2010). Towards a typology of cross-media news consumption: a qualitative-quantitative synthesis. Northern Lights: Film and Media Studies Yearbook, 8(1), 115-137. doi:10.1386/ nl.8.115_1

Silverstone, R. (Ed.). (2005). Media, technology and everyday life in Europe. Aldershot: Ashgate.

Swidler, A., \& Arditi, J. (1994). The New Sociology of Knowledge. Annual Review of Sociology, 20, 305-329.

Tewksbury, D., \& Rittenberg, J. (2012). News on the Internet. New York: Oxford University Press.

Tuchman, G. (1978). Making News. New York: Free Press.

Umbricht, A., \& Esser, F. (2013). Changing Political News? Long-Term Trends in American, British, French, Italian, German, and Swiss Print Media Reporting. In R. Kuhn \& R.K. Nielsen (Eds.), Political Journalism in Transition: Western Europe in a Comparative Perspective (pp. 195-218). London: I.B.Tauris.

Webster, J.G., \& Ksiazek, T.B. (2012). The Dynamics of Audience Fragmentation. Journal of Communication, 62(1), 39-56. doi:10.1111/j.1460-2466.2011.01616.x

Williams, B.A., \& Delli Carpini, M.X. (2011). After broadcast news. New York: Cambridge University Press.

\section{Notes}

1 See for example Deen Freelon's very interesting co-citation map of 9 communication journals covering the period 2003-2013: http://dfreelon.org/2013/09/05/co-citation-map-of-9-comm-journals-2003-2013/ (accessed September 10, 2013).

2 There are even some who argue that quantitative studies have by now become a "poor relation" relative to more widespread and popular qualitative approaches to audience research (e.g., Deacon \& Keightley, 2011).

3 http://www.tandfonline.com/action/journallnformation?show=aimsScope\&journalCode=upcp20\#. Ui8DRT_3NPk (accessed September 10, 2013).

4 Intellectual diversity is not necessarily a value in itself, only in so far as it advances our understanding of our objects of analysis. The introduction of spectrum analysis or the basic theory of particle physics would increase intellectual diversity in political communication research, but it is doubtful they can tell us much about the role of the sharing of symbols in time and space for the authoritative allocation of values in a society and the constitution of authority, values, and societies (which I consider the subject matter of political communication research, phrased in general terms).

Rasmus Kleis Nielsen
Associate Professor, PhD.

Department of Communication, Business, and Information Technologies, Roskilde University

Research Fellow

Reuters Institute for the Study of Journalism

University of Oxford

rasmuskleisnielsen@gmail.com 